\title{
Manajemen Anestesi pada Pasien dengan Akromegali yang Menjalani Prosedur Reseksi Tumor Adenohipofise melalui Pendekatan Sublabial Transphenoidal
}

\author{
Hamzah $^{*}$, Muhammad Faris ${ }^{* *)}$, Yoppie Prim Avidar*), Nancy Margarita Rehatta*) \\ ${ }^{*}$ Departmen/SMF Anestesiologi and Reanimasi, ${ }^{* *}$ Departemen/SMF Bedah Saraf Fakultas Kedokteran Universitas \\ Airlangga- RSUD Dr. Soetomo, Surabaya
}

\begin{abstract}
Abstrak
Akromegali merupakan penyakit akibat produksi growth hormone secara berlebihan dan umumya disebabkan oleh adenoma kelenjar hipofisis. Insidensi akromegali pertahunnya mencapai 5 kasus per 1 juta orang dengan prevalensi 60 kasus per 1 juta orang. Manifestasi klinis pada tiap pasien berbeda, tergantung dari kadar dari growth hormone, insulin-like growth factor-1, usia pasien, ukuran tumor, dan keterlambatan diagnosis. Pasien dengan akromegali telah dilaporkan memiliki tingkat mortalitas dan morbiditas yang tinggi, peningkatan angka kematian pada umumnya terkait dengan komplikasi kelainan kardiovaskular, serebrovaskular dan masalah respirasi. Pada kasus ini, seorang laki-laki usia 57 tahun, berat badan $86 \mathrm{~kg}$, dengan PS-ASA II, perawakan khas akromegali dan ditunjang dengan hasil pemeriksaan hormon. Pada pemeriksaan CT-scan ditemukan massa di ruang sella tursica. Pemeriksaan lebih lanjut menunjukkan pembesaran lidah yang menimbulkan kesulitan manajemen jalan nafas dan diklasifikasikan sebagai mallampati kelas II. Pasien akan dilakukan prosedur reseksi tumor adenohipofise melalui pendekatan sublabial transpheonidal dengan anestesi umum. Sebagian besar anestesi untuk operasi pada pasien akromegali membutuhkan perhatian khusus dibandingkan dengan tumor kepala yang lain..
\end{abstract}

Kata kunci: Akromegali, manajemen anestesi, pendekatan sublabial transfenoid, tumor adenohipofisis

JNI 2018;7(3): 175-84

\section{Anesthesia Management in Patients with Acromegaly Underlying Adenohipofise Tumor Resection Procedures Through a Transphenoidal Sublabial Approach}

\begin{abstract}
Acromegaly and gigantism are clinical abnormalities due to excessive growth hormone production, usually resulted from pituitary adenoma. The incidence of acromegaly is 5 cases per 1 million people per year while the prevalence is 60 cases per 1 million people. Clinical manifestations in each patient is depending on the levels of growth hormone, insulin-like growth factor-1, age of the patient, tumor size and the delay in diagnosis. Increased of morbidity and mortality have been reported in acromegaly patients predominantly caused by complications of cardiovascular, cerebrovascular and respiratory problem. A 57 year old male, $86 \mathrm{kgs,}$ ASA physical status II. His appearance suggested acromegaly, diagnosis then confirmed with hormonal examination and imaging of the pituitary mass. Further examination presented tongue enlargement which cause airway management difficulty and classified as mallampati class II. The patient will undergo adenohipofise tumor resection procedures through a transphenoidal sublabial approach with general anaesthesia. Most of anaesthesia in acromegaly patient surgery require special attention compared with other head tumors.
\end{abstract}

Key words: Acromegaly, management anaesthesia, sublabial transphenoidal approach, adenohipophyse tumour

JNI 2018;7(3): 175-84 


\section{Pendahuluan}

Akromegali merupakan penyakit yang sangat menarik oleh karena menimbulkan tantangan klinis untuk para ahli endokrin lebih dari 130 tahun setelah Pierre Marie menggambarkan penyakit ini. ${ }^{1}$

Akromegali adalah penyakit akibat produksi Growth Hormon $(\mathrm{GH})$ yang berlebih. Penyakit ini umumnya disebabkan oleh adenoma kelenjar hipofisis, suatu bentuk tumor jinak yang baru terjadi setelah usia dewasa. Pasien dengan akromegali telah dilaporkan meningkatkan morbiditas dan mortalitas, terutama bila terjadi persisten GH. Angka harapan hidup dapat menurun kurang lebih 10 tahun terutama bila kadar GH tidak terkendali dan timbul komplikasi seperti penyakit jantung dan diabetes mellitus. ${ }^{1,2}$ Diagnosa akromegali paling sering ditegakkan setelah umur 50 tahun, angka kejadian pertahun 5 kasus per 1 juta orang sedangkan prevalensi 60 kasus per 1 juta orang, rasio antara laki-laki dan wanita adalah sama. ${ }^{3}$ Adenoma hipofisis adalah kelompok tumor yang berasal dari kelenjar hipofisis. Tumor ini telah diklasifikasikan berdasarkan ukuran menjadi mikroadenoma bila diameternya kurang dari $10 \mathrm{~mm}$, makroadenoma bila ukurannya lebih dari $10 \mathrm{~mm}$ dan giant adenomas jika lebih dari $30 \mathrm{~mm}$. Klasifikasi saat ini telah dilengkapi dengan sistem yang lebih komprehensif. ${ }^{4}$

Adenoma hipofisis yang menjadi penyebab akromegali, dapat memproduksi satu atau lebih hormon secara berlebih, sehingga sering juga disebut sebagai secretory pituitary adenomas. Jenis tumor ini tidak akan meluas keluar dari kranium, umumnya tetap berada di sella turcica (ruang kecil tempat kelenjar hipofisis). ${ }^{3}$ Kasuskasus tertentu dapat bertumbuh ke luar dinding sella tursika dan disekitar pembuluh darah, nervus dan selaput otak sehingga dapat menimbulkan gejala klinis tertentu sesuai dengan luas daerah yang terpapar. ${ }^{3}$ Manifestasi klinis setiap penderita bervariasi tergantung dari ukuran tumor, kadar GH and Insulin-like Growth Factor-1 (IGF-I), umur dan keterlambatan diagnosis. Umumnya gejala akromegali yang ditemukan disebabkan oleh ketidakseimbangan hormonal dengan manefestasi klinis seperti keringat berlebih perbesaran jari dan tangan, kaki, dan pembesaran tulang wajah yang abnormal seperti tulang pipi dan tulang dagu. Gejala lain yang sering menyertai adalah hipertensi, pembesaran jantung, kelemahan otot jantung hingga gagal jantung dan gagal nafas. Kelainan patologis lain yang dapat ditemukan adalah gangguan toleransi glukosa dan diabetes Mellitus (DM), metabolism lemak yang tidak normal, polip colon, letak gigi berubah (teeth spacing), kulit berminyak dan berjerawat. ${ }^{3}$ Penyakit yang mirip dengan akromegali adalah gigantisme, yang juga disebabkan oleh sekresi berlebihan dari hormon pertumbuhan (GH), namun gigantisme terutama ditemukan pada usia muda sedangkan akromegali baru terjadi setelah usia dewasa. ${ }^{3}$

Masalah unik yang akan dihadapi spesialis anestesi pada kasus akromegali adalah perubahan anatomi seperti pembesaran lidah, yang diikuti perubahan pada laring, pembesaran hidung, protrusi mandibular dengan maxilla yang melebar, maloklusi rahang dan gigi serta jaw overbite, sehingga dapat menimbulkan masalah pengelolaan jalan nafas, perubahan anatomi ini digunakan sebagai antisipasi pengelolaan intubasi yang berdampak pada hemodinamik. Pemahaman mengenai penilaian pra bedah, tata laksana selama pembedahaan dan komplikasi yang mungkin terjadi, cara-cara pencegahan komplikasi merupakan dasar keberhasilan penanganan pasien perioperatif sehingga mencegah morbiditas dan mortalitas. ${ }^{3}$

\section{Kasus}

Seorang laki-laki 57 tahun, berat badan $86 \mathrm{~kg}$, status fisik-ASA II masuk ke rumah sakit dengan rencana operasi transnasal transphenoidal. Pasien menunjukkan tanda akromegali dan dianjurkan untuk menjalankan pemeriksaan lebih lanjut, ternyata pasien mengalami tumor kelenjar hipofisis (Pitutary Adenoma) dan terdiagnosa sebagai akromegali.

\section{Pemeriksaan Prabedah}

\section{Anamnesis}

Anamnesa didapatkan riwayat penyakit sistemik berupa hipertensi yang mendapatkan terapi 
ramipril dan diabetes mellitus yang terkontrol dengan glimepiride. Saat ini pasien mengeluhkan sering berkeringat, pusing, penurunan libido dan pembesaran ukuran tangan dan kaki secara bertahap.

\section{Pemeriksaan Fisik}

Pada pemeriksaan fisik didapatkan pembesaran ukuran tangan dan kaki serta masalah jalan nafas berupa lidah yang besar sehingga tergolongkan sebagai Mallampati klas 2. Evaluasi foto thorak didapatkan kardiomegali dan EKG menunjukan adanya hipertrofi ventrikel kiri. Selama mendapatkan pengobatan dengan ramipril, tekanan darah terendah 140/95 $\mathrm{mmHg}$ dan tekanan darah tertinggi $160 / 100 \mathrm{mmHg}$

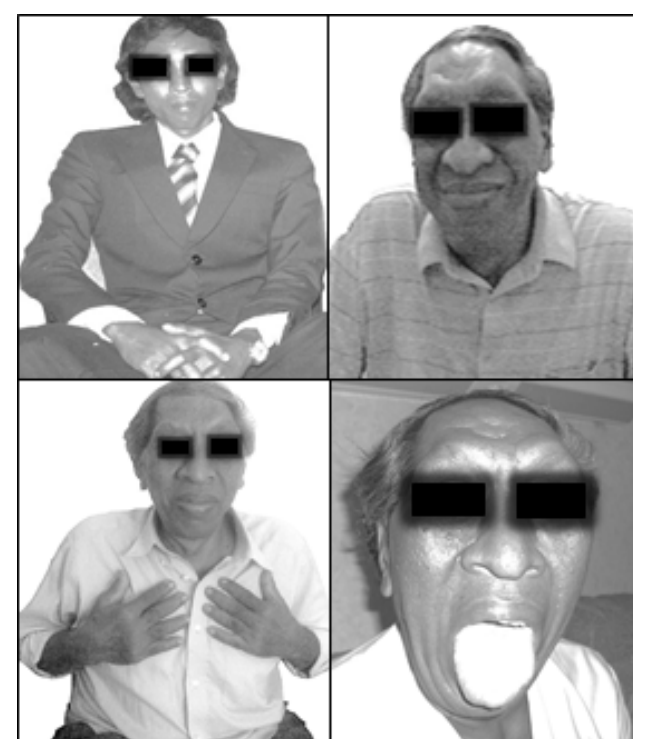

Gambar 1. Foto Pada Umur Berbeda Menunjukkan Perubahan Fisik pada Wajah, Tangan dan Lidah Pasien Akromegali

\section{Pemeriksaan Laboratorium}

Oleh karena keterbatasan pada fasilitas laboratorium, hanya dilakukan evaluasi kadar hormon serum (Tabel 1). Evaluasi kadar hormon menunjukan peningkatan prolaktin (PRL) dan $\mathrm{GH}$, serta penurunan testosteron, sedangkan kadar thyroid-stimulating hormon (TSH), kortisol dan follicle stimulating hormon (FSH) dan luteinizing hormone (LH) normal.

\section{Pemeriksaan Radiologi}

Gambaran Magnetic Resonance Imaging (MRI)

Kepala menunjukan adanya massa di sella tursica (Pituitari Fossa) yang termasuk sebagai makroadenoma $(2 \times 2 \times 3 \mathrm{~cm})$ sebagian besar membesar ke inferior masuk sampai mengisi sebagian sinus sphenoidalis namun ke superior belum menyebabkan penekanan chiasma.
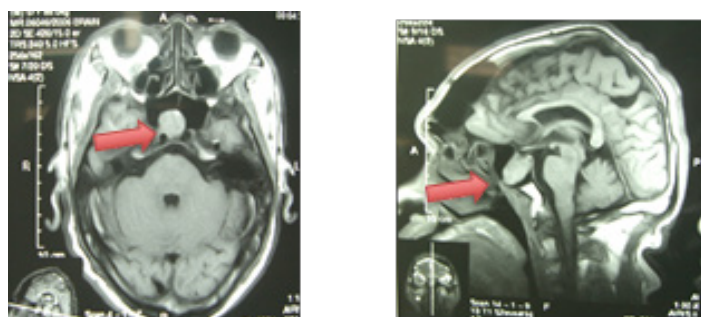

Gambar 2. Foto MRI Kepala Pra Bedah . Panah menunjukkan adenoma hipofise

\section{Penatalaksanaan Anestesi}

Pasien akan dilakukan prosedur reseksi tumor adenohipofise melalui pendekatan sublabial transpheonidal dengan anestesi umum dan lama operasi $\pm 2 \mathrm{jam}$. Premedikasi dengan hidrocortison $100 \mathrm{mg}$, atropine $0,5 \mathrm{mg}$, lidocain $0,8 \mathrm{mg} / \mathrm{kgBB}$. Induksi anestesi dilakukan dengan menggunakan thiopental $5 \mathrm{mg} / \mathrm{kgBB}$, atracurium $0,6 \mathrm{mg} / \mathrm{kgBB}$ dan $1 \mu \mathrm{g} / \mathrm{kgBB}$ fentanil iv, dilanjutkan dengan

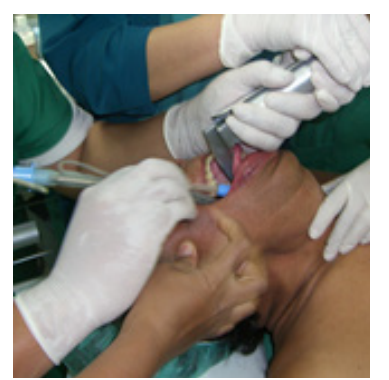

Gambar 3. Lidah Yang Membesar dan Proses Intubasi Pasien

rumatan menggunakan nitrous oxide $50 \%$ dalam oksigen (dengan fasilitas mesin anestesi tanpa air), isoflurane $0,7 \%$ dan fentanil.

Jalan nafas dipertahankan dengan oro pharyngeal airway dan chin lift selama 3 menit dan diberikan nafas buatan pasca pemberian atracurium sebagai fasilitas untuk intubasi dengan menggunakan 
Tabel 1. Hasil Pemeriksaan Hormonal Pasien

\begin{tabular}{llll}
\hline Hormona & Prabedah & Normal Value & $\begin{array}{l}\text { Pascabedah } \\
(5 \text { minggu })\end{array}$ \\
\hline GH & $65 \mathrm{ng} / \mathrm{mL}$ & $<1$ & $2,6 \mathrm{ng} / \mathrm{ml}$ \\
Prolactin (EIA) & $444 \mathrm{ng} / \mathrm{ml}$ & $2,5-17 \mathrm{ng} / \mathrm{ml}$ & $16.0 \mathrm{ng} / \mathrm{ml}$ \\
TSH ( EIA) & $1.02 \mu \mathrm{IU} / \mathrm{ml}$ & $0,4-4 \mu \mathrm{IU} / \mathrm{ml}$ & $0,32 \mu \mathrm{IU} / \mathrm{ml}$ \\
T3 (MEIA) & $1.31 \mathrm{ng} / \mathrm{ml}$ & $0,79-1,49 \mathrm{ng} / \mathrm{mL}$ & $1,12 \mathrm{ng} / \mathrm{ml}$ \\
T4 ( EIA) & $1.11 \mu \mathrm{g} / \mathrm{dl}$ & $4,5-12,5 \mu \mathrm{g} / \mathrm{dl}$ & $13,50 \mu \mathrm{g} / \mathrm{dL}$ \\
LH (EIA) & $1.3 \mathrm{mIU} / \mathrm{ml}$ & $0,8-7,6 \mathrm{mIU} / \mathrm{ml}$ & $5 \mathrm{mIU} / \mathrm{ml}$ \\
Cortisol (EIA) & $107 \mathrm{ng} / \mathrm{ml}$ & $50-250 \mathrm{ng} / \mathrm{mL}$ & $59 \mathrm{ng} / \mathrm{mL}$ \\
Testoteron (EIA) & $71.2 \mathrm{ng} / \mathrm{dL}$ & $181-758 \mathrm{ng} / \mathrm{dL}$ & $300 \mathrm{ng} / \mathrm{dL}$ \\
FSH (EIA) & $8.5 \mathrm{mlU} / \mathrm{ml}$ & $0.7-11.1 \mathrm{mlU} / \mathrm{ml}$ & $10,3 \mathrm{mlU} / \mathrm{ml}$ \\
\hline
\end{tabular}

Keterangan: GH: Growth Hormone, TSH: Thyroid-Stimulating Hormone, T3: Triiodothyronine, T4:Thyroxine, FSH: Follicle-Stimulating Hormone, EIA: Enzyme Immunoassay, MEIA: Microparticle Enzyme Immunoassay

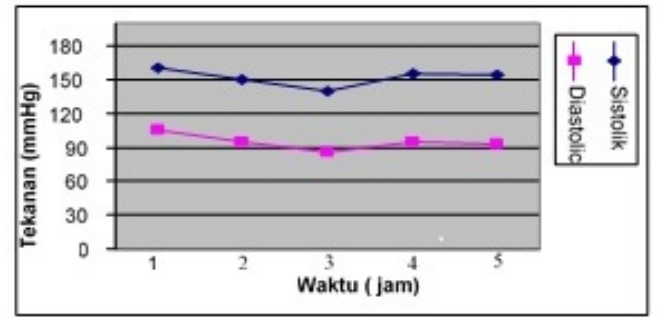

Gambar 4. Tekanan Darah Rerata Selama di Ruang Pulih Sadar

pipa endotrakhea no $8.0 \mathrm{~mm}$ melalui mulut dan diberikan tampon dengan sangat hati hati. Saat melakukan laringoskopi dan intubasi sedikit dibutuhkan tenaga untuk melakukannya, pipa endotrakhea dimasukkan dan balon dikembangkan dengan tekanan $<20 \mathrm{~cm} \mathrm{H}_{2} \mathrm{O}$ dan difiksasi di dagu. Ekstubasi dilakukan saat pasien sudah sadar penuh dan bisa diperintah.

\section{Pascabedah}

Setelah dilakukan ekstubasi, pasien dibawa ke ruang pulih sadar. Nyeri pasca operasi diatasi dengan menggunakan morphin, tekanan darah distabilkan dengan diltiazem, dan kadar gula darah dipertahankan dengan insulin dan glimeperide. Pemberian obat untuk diabetisnya tidak lagi dilanjutkan setelah hari ke 9 pasca pembedahan, tatalaksana hipertensinya masih menggunakan ramipril. Segera setelah pasien dapat menelan pasien diberikan bromokriptin per

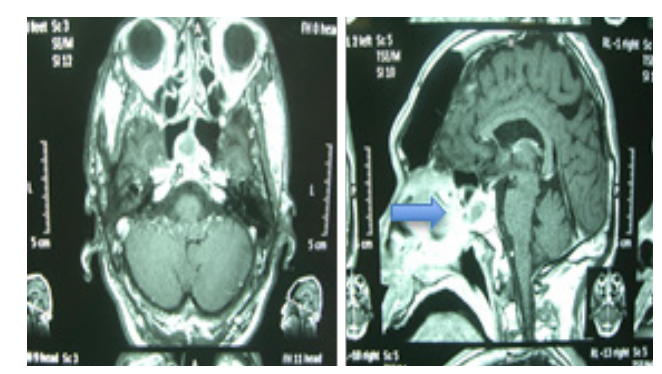

Gambar 5. Foto MRI Kepala Pascabedah Eksisi Adenoma Hipofisa Melalui Sublabial Transphenoidal

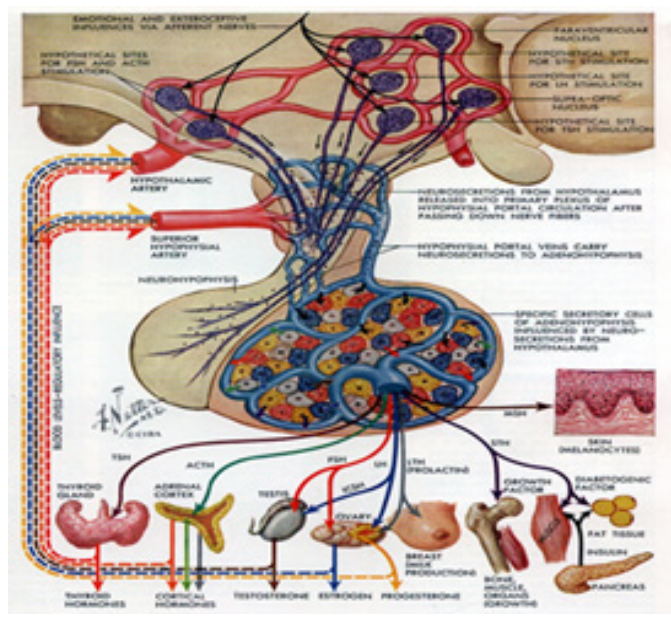

Gambar 6. Kelenjar Hipofisis Normal ${ }^{5}$

Tampak bagian adenohipofisis yang kaya akan pembuluh dan bermacam sel yang dapat mensekresi berbagai hormon dan yang dapat distimulasi oleh hipotalamus 
oral untk mempertahankan kadar prolaktin.

Penanganan setelah pembedahan pada pasien ini mempunyai resiko bermasalah pada jalan nafas dan diabetes insipidus, sehingga dibutuhkan pengawasan ketat. Pasien ini dipulangkan hari ke 12 setelah pembedahan.

\section{Pembahasan}

Akromegali adalah suatu penyakit dengan kelainan hormonal dimana disebabkan oleh produksi GH yang berlebih. Insiden tumor hipofisis didapatkan antara 10\%-25\% dari seluruh neoplasma intrakranial. ${ }^{3}$ Diagnosa akromegali sering terlambat ditegakkan, terkadang setelah penderita 25 tahun mengalami kelainan hormonal diagnosa baru dapat ditegakkan. Hal ini disebabkan karakteristik adenoma hipofisis yang sangat jarang yang menampakkan gejala yang signifikan. Sehingga biasanya ditemukan secara insidental ketika penderita berobat kedokter dengan penyakit bukan tumor yang diderita. ${ }^{6}$ Pada kasus ini, diagnosa akromegali ditegakkan pascabedah herniotomi penderita hernia inguinalis dan dicurigai terdapat manifestasi gangguan GH seperti pada foto 1 . Kemudian dianjurkan dilakukan pemeriksaan laboratorium dan didapatkan peningkatan kadar prolaktin dan GH, serta penurunan testosteron. Tumor hipofisis berdasarkan ukurannya dibagi atas mikroadenoma $(<10 \mathrm{~mm})$ dan makroadenoma $(\geq 10 \mathrm{~mm})$ dan giant adenomas saat berukuran lebih dari 30 atau $40 \mathrm{~mm},{ }^{4}$ pembagian lain adalah berdasarkan biological behavior, yakni kelompok adenoma yang sekarang diklasifikasi berdasarkan immunohistochemistry dan status fungsional. ${ }^{3}$ Tujuan klasifikasi tambahan ini untuk menentukan manifestasi dan tingkat resiko mortalitas yang semakin tinggi, sebanding dengan makin besarnya tumor kelenjar hipofisis, dan tidak terkendalinya kadar GH. ${ }^{7}$ Berdasarkan temuan histopatologis, radiologis dan klinisnya tumor hipofisis dapat diklasifikasikan menjadi 3 kelompok yaitu adenoma jinak, adenoma invasif, dan karsinoma. ${ }^{7}$

Adenoma jinak mencakup sebagian besar dari kasus neoplasma hipofisis dengan estimasi prevalensi keseluruhan diperkirakan sekitar 10 hingga $15 \%$. Hanya sebagian kecil dari adenoma yang menimbulkan gejala. Adenoma adalah tumor dengan morfologi sel yang homogen dan memiliki aktivitas mitosis yang normal (Ki-67 labeling index $<3 \%$ ). Adenoma dapat diklasifikasikan sebagai adenoma agresif saat memiliki risiko tinggi kekambuhan atau kurangnya respon terapeutik terhadap pengobatan konvensional, adenoma agresif biasanya berukuran lebih besar, lebih cepat tumbuh. ${ }^{7}$ Adenoma invasif didefinisikan sebagai tumor dengan pertumbuhan yang terbukti ke struktur yang berdekatan, seperti sinus kavernosa, tulang, dan sinus sphenoid, kecuali pertumbuhan ke suprasellar yang tidak dianggap sebagai kriteria invasif. Invasi dapat dideteksi dengan MRI pra-bedah, selama pembedahan, atau dengan demonstrasi histologis penyebaran tumor ke dura, tulang, atau mukosa hidung. ${ }^{7} \quad$ Karsinoma hipofisis didefinisikan ketika didapatkan metastase sistemik atau di cairan serebrospinal bahkan jika mereka tidak menunjukkan fitur ganas histologis umum seperti aktivitas mitosis yang lebih tinggi, tumor ini jarang terjadi dengan angka insidensi $0,2 \%$ dari seluruh tumor pituitari. ${ }^{4}$

Peningkatan dari morbiditas dan mortalitas yang berhubungan dengan akromegali adalah hasil dari sekresi berlebih dari GH dan IGF-1 dan dari efek massa dari tumor hipofisis. Diagnosis dini dari penyakit ini sangat penting sekalipun tidak satupun dari gejala ini cukup sensitif, terutama saat tahap awal dari penyakit ini. ${ }^{6}$ Akromegali sendiri memiliki berbagai tanda dan gejala yang umumnya didasari atas efek GH. Produksi berlebih dari GH menstimulasi dari hormon lain melalui hepar yaitu IGF-1. Hormon inilah yang menstimulasi pertumbuhan dari kulit, jaringan ikat, kartilago, tulang, organ, dan jaringan lain dalam tubuh; dengan pengecualian tulang dari ekstremitas, yang mana tidak tumbuh lagi setelah masa puber. Resiko lain yang sering ditemukan adalah penurunan libido yang disebabkan menurunnya produksi testosteron oleh karena penekanan pada sel yang memproduksinya. ${ }^{8}$ GH dalam darah akan menstimulasi hati untuk memproduksi IGF-1. IGF-1 bersifat mitogenik dan menghambat apoptosis, dan penelitian pada hewan menunjukkan GH dapat meningkatkan 
resiko hiperplasia dan keganasan. Lebih lagi bukti epidemiologis menunjukkan bahwa aksis GH/ IGF-I mempengaruhi resiko kanker pada manusia. Kadar GH berlebih ini akan mempengaruhi proses mitogenik dan antiapoptotik pada tingkat sel. Pada perangsangan GH di hepar, telah terbukti secara in-vitro menyebabkan efek karsinogenik (mitosis dan antiapoptotis) dan hiperplasia. Hasil dari studi kohort menunjukkan, sekalipun tidak konsisten, peningkatan IGF-1 dalam serum memprediksi peningkatan resiko kanker tertentu, dan ada bukti di mana resiko kanker tiroid, payudara dan usus besar meningkat pada pasien dengan akromegali, kelainan yang disebabkan oleh GH yang berlebih. ${ }^{9}$

Wajah dan kepala (hidung, bibir, dan dahi) melebar, membesar dan tampak bengkak. Penonjolan tengkorak regio frontalis dan cranial ridge, pertumbuhan berlebih dari mandibular dengan prognathism, pelebaran maxilla dengan gigi yang terpisah, maloklusi rahang, dan overbite. Lidah membesar, jarak antar gigi melebar, rahang bawah membesar. ${ }^{3}$ Leher - Pertumbuhan jaringan lunak dari leher dan kotak suara dapat memicu pada suara serak atau sleep apnea (kondisi yang dapat menyebabkan seseorang kadang berhenti bernafas sesaat saat tidur, mengakibatkan penurunan kadar oksigen, mengganggu tidur, dan mengantuk pada siang hari).

Tangan dan kaki membesar, sehingga pasien memerlukan ukuran cincin, sarung tangan, dan sepatu yang sangat besar. Pertumbuhan dari jaringan di pergelangan tangan, dapat menekan saraf medianus di pergelangan tangan dan menimbulkan kesemutan atau nyeri di tiga jari tangan (Carpal Tunnel Syndrome). Tulang Pertumbuhan berlebih dari tulang dapat merusak kartilago di sekitarnya dan memicu seringnya terjadi arthritis.

Jantung - Insidensi dari penyakit jantung pada penderita akromegali meningkat, hal ini diduga karena pembesaran otot jantung yang mengganggu fungsi dari otot (kardiomiopati). Tekanan darah tinggi juga lebih umum pada akromegali. Beberapa orang memiliki masalah pada katup jantungnya. Gagal jantung dapat terjadi bila akromegali tidak terkontrol. ${ }^{10}$ Pada kondisi di mana kadar GH tidak terkontrol dan disertai penyakit jantung, angka harapan hidup dapat berkurang kurang 10 tahun. Pasien dengan akromegali yang terawat dan memiliki kadar GH normal umumnya memiliki angka harapan hidup yang normal oleh karena sebagian perubahan jaringan dapat reversibel. Kelainan kardiovaskuler lain yang juga sering menyertai adalah resiko terjadinya arterioskelerotik. ${ }^{1,3}$

Diabetes lebih umum pada orang dengan akromegali, dan orang yang sebelumnya didiagnosa dengan diabetes, kemungkinan akan memerlukan dosis terapi yang lebih tinggi. ${ }^{11}$ Diabetes pada penyakit akromegali disebabkan oleh kelebihan kadar GH yang mengganggu metabolisme glukosa, hal ini telah dibuktikan pada binatang coba di mana pemberian GH secara terus menerus (increasing doses of $\mathrm{GH}$ ) didapatkan kerusakan sel beta, yang dimulai dengan peningkatan insulin, degranulasi, peningkatan mitosis dan proliferasi sel. Pemberian terus menerus berlanjut pada fibrosis and hyalinisasi dari pulau - pulau pankreas, sehingga masuk pada tahap ireversibel dan diabetes menjadi permanen. Peningkatan GH juga mengurangi pengambilan (uptake) glukosa oleh otot dan jaringan adipose dengen konsekuensi peningkatan kadar gula darah. ${ }^{11}$

Gejala lain dapat disebabkan oleh ukuran dari adenoma hipofisis, jika adenoma hipofisis menjadi lebih besar (contoh: $2 \mathrm{~cm}$ atau lebih) akan menyebabkan tekanan pada struktur di sekitar akan menimbulkan gejala. Jika adenoma tumbuh ke atas, hal ini dapat menimbulkan peregangan pada saraf mata (chiasma optikus) yang menyebabkan masalah penglihatan dimulai dengan gangguan lapang pandang dan apabila berlanjut akan menimulkan kebutaan. ${ }^{1}$

GH menstimulasi produksi zat kimiawi lain, seperti insulin-like growth factor-1 (IGF-1) di hati dan banyak jaringan tubuh lainnya. Sehubungan dengan adanya kaitan antara kelebihan GH dan kelebihan IGF-I, maka pengukuran kadar IGF-1 darah dianggap cukup mewakili atau dianggap sudah efektif jika hanya mengukur 
IGH-I untuk mewakili kadar GH dalam darah atau sebaliknya. Diagnostik lain adalah imaging kepala menggunakan MRI untuk melihat kelenjar hipofisis dan hipothalamus. ${ }^{3}$ Pada pemeriksaan MRI kepala hampir selalu diperlukan pemberian| kontras gadolinium, dengan teknik T1 weighted, dengan resolusi tinggi akan mudah diketahui adanya tumor hipofisa. Sebagai tambahan pemeriksaan darah dan urin untuk mendapatkan diagnose perubahan endokrin bisa dilakukan untuk menentukan kadar hormon basal PRL, GH, IGF-1, free thyroxine, kortisol dan testosteron (pada pria). ${ }^{1}$ Namun oleh karena keterbatasan dari pemeriksaan laboratorium, pada pasien ini hanya dilakukan pemeriksaan pada tabel 1 dan didapatkan peningkatan kadar PRL dan GH, serta penurunan testosteron.

GH menstimulasi produksi zat kimiawi lain, seperti insulin-like growth factor-1 (IGF-1) di hati dan banyak jaringan tubuh lainnya. Sehubungan dengan adanya kaitan antara kelebihan GH dan kelebihan IGF-I, maka pengukuran kadar IGF-1 darah dianggap cukup mewakili atau dianggap sudah efektif jika hanya mengukur IGF-I untuk mewakili kadar GH dalam darah atau sebaliknya. ${ }^{12}$ Namun terkadang hasil pemeriksaan laboratorium sudah jelas menunjukkan bahwa pasien mengalami kelebihan GH, Tapi MRI sering sulit memastikan adanya mikroadenoma yang kecil karena memerlukan teknik pembuatan imaging yang teliti. Apabila sudah dilakukan pemeriksaan MRI yang teliti dan tetap tidak ditemukan adanya mikroadenoma maka harus dicoba mencari alternatif pemeriksaan lain yaitu berusaha melacak atau menemukan jenis tumor lain di organ tubuh diluar kelenjar hipofisis, yang mempengruhi pelepasan GH di kelenjar hipofisis (Growth Hormone-releasing hormone). Biasanya berasal dari tumor di paru, gastrointestinal atau pankreas. Produksi hormon ektopik ini mempunyai kapasitas untuk menstimulasi pelepasan hormon yang berlebihan dari kelenjar hipofisis. ${ }^{13}$

Lingual Tonsil hypertrophy (LTH) seringkali asimptomatis, sekalipun beberapa pasien mungkin merasakan rasa mengganjal di leher, perubahan suara, batuk kronis, mendengkur, atau obstructive sleep apnoea. Dua dari 3 pasien dengan LTH memiliki riwayat tonsilektomi palatum. Hal ini dapat mengakibatkan LTH, kemungkinan karena mekanisme kompensasi karena hilangnya tonsil palatum. LTH kebanyakan terjadi pada orang dewasa, terutama pada individu dengan atopi, namun hal ini juga dilaporkan terjadi pada anak. ${ }^{14}$ LTH dapat menggeser epiglottis ke arah posterior dan membuat mobilisasi epiglotis lebih sulit. Hal ini mungkin penyebab kenapa pasien dengan LTH lebih sulit diiintubasi menggunakan teknik konvensional. Intubasi dengan fiberoptik pada pasien yang telah dianestesi mungkin sama sulitnya. Pergeseran epiglotis ke arah posterior dan jaringan berlebih dapat mengganggu pandangan fiberoptik, dan dengan onset dari blokade neuromuskular yang menyebabkan relaksasi dari otot faring, menyebabkan pergeseran ke arah posterior yang lebih lagi dari lidah dan epiglotis. Kegagalan yang serupa dari intubasi dengan laryngeal mask telah dilaporkan sebelumnya. Perlu kehati-hatian untuk tidak menimbulkan trauma jaringan, dan pasien dalam semua kondisi lebih mudah untuk diberi ventilasi dengan face mask. Sekalipun perdarahan minimal terjadi, hal ini tetap dianggap aman untuk dilakukan. Insidensi LTH dipercaya rendah, namun oleh karena hal ini sering asimtomatis, kemungkinan hal ini tidak terdeteksi hingga dilakukan anestesi umum. ${ }^{14}$ Seperti tonsil lain, tonsil lingua dapatmembengkak saat terjadi inflamasi akut dan berlanjut pada masalah jalan nafas. Ada laporan di mana pasien LTH dan jalan nafas sulit yang tidak terduga yang telah diintubasi beberapa minggu sebelumnya tanpa masalah. Intubasi dengan fiberoptik dalam kondisi sadar direkomendasikan untuk semua pasien dengan LTH yang memerlukan anestesi umum. Dalam situasi intubasi sulit yang tidak diduga, disarankan menggunakan laringoskop THT. ${ }^{15}$

Akromegali diketahui berkaitan dengan peningkatan resiko dari jalan nafas sulit dan insidensi dari kesulitan intubasi dilaporkan berkisar 10 hingga $30 \%$. Hal ini berkontribusi pada prognathism, macroglossia dan penebalan dari jaringan lunak laring dan faring, serta LTH pada pasien kami yang mana berkontribusi sebagai penyulit intubasi. ${ }^{3}$ Kemungkinan ada pengaruh sinergis dari akromegali, menyebabkan 
tonsil lingua lebih hipertrofi dari biasanya. Namun, oleh karena penemuan pre-operasi, dan konfirmasi LTH besar melalui endoskopi, kami percaya bahwa LTH adalah alasan utama dalam kesulitan kami, utamanya menyebabkan penggeseran epiglotis ke arah posterior. LTH dengan resiko pembengkakan dan perdarahan harus selalu dipertimbangkan pada saat menemui kesulitan dalam memvisualisasikan pita suara dengan laringoskop rigid. ${ }^{15}$

Terapi spesifik untuk adenoma dikoordinasi oleh Spesialis Bedah Saraf dan Spesialis Penyakit Dalam Endokrin yang tergabung dalam tim tumor hipofisis. Terapi dapat mencakup operasi, termasuk operasi pengangkatan melalui prosedur yang disebut Sublabial Transphenoidal atau Endonasal Transphenoidal Endoscopic Surgery, terapi medis, terapi radiasi, terapi hormon, dan atau observasi. ${ }^{16}$ Terapi untuk akromegali memiliki tujuan untuk mengurangi atau mengendalikan pertumbuhan tumor, menghambat hipersekresi GH, dan menormalkan kadar IGF-1. Terapi saat ini menggunakan tiga pendekatan yaitu, pembedahan, manajemen medis, dan radioterapi. Setiap modalitas terapi memiliki keuntungan dan kerugian spesifik, namun penggunaan optimum dari terapi ini bertujuan mengurangi mortalitas pada populasi pasien akromegali. Namun radioterapi lebih diarahkan apabila tindakan bedah gagal mengambil semua tumor sehingga masih ada bagian tumor yang memproduksi GH. ${ }^{16}$

Tujuan utama pada pengobatan akromegali dengan manajemen medis adalah dengan merestorasi kadar GH/IGF ke arah normal. IGF1 merupakan penanda yang baik dari jumlah total sekresi GH sehingga dapat digunakan sebagai penanda utama dalam mengendalikan akromegali. Pada pasien yang terkontrol, kadar IGF-1 akan berada pada kadar yang normal dalam kelompok usia dan jenis kelamin masing - masing pasien. Tujuan dari terapi biokimia dari akromegali adalah untuk mengembalikan aksis GH/IGF-1 ke dalam batas normal. ${ }^{17}$ Pada fasilitas yang memiliki pemeriksaan lab yang lengkap sebaiknya pemeriksaan IGF-1 dilakukan oleh karena peningkatan sekresi dari GH menyebabkan peningkatan produksi IGF-1. ${ }^{18}$ Berdasarkan bukti terbaru, kadar GH kurang dari 2-2.5 mug/L adalah prediktor yang lebih baik dibandingkan kadar IGF-1 yang normal, hal ini kemungkinan disebabkan oleh perbedaan antara GH and IGF1 pada kadar GH yang rendah. ${ }^{19}$ Beberapa bukti menyarankan batas kadar GH yang lebih ketat (kurang dari $1 \mu \mathrm{g} / \mathrm{L}$ ). Radioterapi berkaitan secara spesifik dengan mortalitas serebrovaskuler dan penggunaannya pada pasien dengan akromegali harus melibatkan analisa keuntungan dan resiko yang teliti pada tiap kasus. ${ }^{18}$ Terapi dengan pegvisomant atau somotostatin analog (octreotide) menghasilkan konsentrasi IGF-I menjadi normal hingga pada $90 \%$ pasien dengan akromegali, termasuk mereka yang mengalami kegagalan dengan modalitas terapi lain. Dengan agen ini, kadar GH dalam sirkulasi meningkat sebagai pengaruh dari penurunan kadar IGF-I. ${ }^{17}$

\section{Komplikasi}

Resiko tindakan anestesi pada kasus akromegali meliputi kesulitan pada penanganan jalan nafas, hipertensi, masalah di jantung, ginjal, diabetes dan sistem endokrin. ${ }^{10}$ Akromegali adalah penyakit serius yang dapat meningkatkan angka kesakitan dan kematian. Kasus ini selama tindakan anestesi tidak didapatkan masalah. Tetapi saat intubasi dibutuhkan tambahan usaha, memasukan tampon dan menggunakan penekanan pada cricoid yang harus hati-hati. Kemungkinan kesulitan saat intubasi membutuhkan penggunaan fiberoptik untuk menghindari komplikasi dan tracheostomi yang sebenarnya tidak diperlukan. Penekanan pada cricoid untuk membantu visualisasi dari laring dan pemasangan tampon harus dilakukan dengan hati-hati. ${ }^{20}$

Observasi hormonal dan MRI setelah operasi sangat penting untuk menentukan pengobatan selanjutnya. Masalah akan meningkat jika terjadi recurrent adenoma yang dapat diobeservasi dari pemeriksaan diatas. Peningkatan hormon yang dihasilkan oleh hipofisis oleh adenoma dapat dihilangkan dengan mengangkat tumor tersebut. Kegagalan bisa terjadi ketika masih ada sisa dari adenoma yang tertinggal. ${ }^{16}$ Berdasarkan data laboratorium pasca bedah didapatkan penurunan prolaktin dan GH (prolaktin menjadi normal tetapi GH masih belum normal), testosteron meningkat 
dan beberapa keluhan hilang. Hal ini menunjukan bahwa adanya perbaikan klinis tetapi masih ada kemungkinan terulang lagi atau timbul lagi. Dari literatur disebutkan bahwa angka kesembuhan setelah pembedahan mencapai $90 \%$ untuk mikroadenoma dan $60 \%$ untuk makroadenoma dengan tingkat rekurensi 2 hingga $8 \%{ }^{16}$

Pada kasus ini tidak ada kejadian perubahan hemodinamik yang bermakna selama operasi, dan komplikasi dari intubasi sulit juga tidak didapatkan. Resiko operasi berupa perdarahan, diabetes insipidus dan syndrom of inappropriate antidiuretic hormone tidak terjadi.

\section{Simpulan}

Terapi spesifik untuk adenoma dikoordinasi oleh Spesialis Bedah Saraf dan Endokrin (spesialis kelainan hormon) dalam tim tumor hipofisis. Terapi dapat mencakup operasi, termasuk operasi pengangkatan melalui prosedur yang disebut Sublabial transphenoidal dan Endonasal transphenoidal endoscopic surgery, terapi medis, terapi radiasi, terapi hormon, dan atau observasi. Pertanyaan yang sering ditanyakan adalah "seberapa efektifkah pembedahan bekerja?" - Tindakan Bedah biasanya efektif dalam mengurangi peningkatan kadar hormon, walaupun kadarnya tidak selalu kembali ke normal. Kemungkinan kadar GH kembali ke kadar normal setelah operasi berkaitan langsung dengan ukuran adenoma sebelum operasi. Kadar dari GH dan IGF-1 akan kembali normal pada $80 \%$ orang dengan mikroadenoma.

Pada sisi lain, kurang dari $40 \%$ dari orang dengan adenoma besar yang melebihi hipofisis akan memiliki kadar hormon normal setelah operasi. Jika adenoma diangkat seluruhnya, kadar GH darah akan langsung turun ke batas normal dalam hitungan jam setelah operasi dan kadar IGF-1 darah akan menjadi normal dalam hitungan minggu sampai bulan. Penelitian yang dipublikasikan menunjukkan bahwa pegvisomant memiliki efikasi yang baik dalam terapi akromegali. Zat ini terbukti aman dan dapat ditoleransi dengan baik, sehingga zat baru ini dapat menjadi pilihan terapi yang penting untuk pasien dengan akromegali.

\section{Daftar Pustaka}

1. Fleseriu M, Gadelha M. Acromegaly, a pituitary special issue. Pituitary 2017; 20: 2-3.

2. Găloiu S, Poiană C. Current therapies and mortality in acromegaly. J. Med. Life 2015; 8: 411-5.

3. Lugo G, Pena L, Cordido F. Clinical manifestations and diagnosis of acromegaly. International Journal of Endoclinology 2012; 2012.

4. Chatzellis E, Alexandraki KI, Androulakis II, Kaltsas G. Aggressive pituitary tumors. Neuroendocrinology 2015; 101: 87-104.

5. Raffa $\mathrm{Rb}$, Rawis $\mathrm{SM}$, Beyazarof EP. Netter's Illustrated Pharmacology, 2014; 57-91.

6. Lavrentaki A, Paluzzi A, Wass JA, Karavitaki N. Epidemiology of acromegaly: review of population studies. Pituitary 2017; 20:4-9.

7. Sav A, Rotondo F, Syro LV, Di Ieva A, Cusimano MD, Kovacs K. et al. Invasive, atypical and aggressive pituitary adenomas and carcinomas. Endocrinol. Metab. Clin. North Am 2015; 44: 99-104.

8. Pastuszak AW, Liu JS, Vij A, Mohamed O, Sathyamoorthy K, Lipshultz LI. et al. IGF1 levels are significantly correlated with patient-reported measures of sexual function. Int. J. Impot. Res 2011; 23: 220-26.

9. Terzolo M, Reimondo G, Berchialla P, Ferrante E, Malchiodi E, De Marinis L. et al. Acromegaly is associated with increased cancer risk: A survey in Italy. Endocr. Relat. Cancer 2017; 24: 495-504.

10. Abreu A, Tovar AP, Castellanos R, Valenzuela A, Giraldo CM, Pinedo AC. et al. Challenges in the diagnosis and management of acromegaly: a focus on comorbidities. Pituitary 2016; 19: 448-57. 
11. Hannon AM, Thompson CJ \& Sherlock M. Diabetes in Patients With Acromegaly. Curr. Diab. Rep 2017; 17: 8.

12. Giustina A, Chanson P, Kleinberg D, Bronstein MD, Clemmons DR, Klibanski A. et al. A consensus on the medical treatment of acromegaly. Nat. Publ. Gr 2014; 10: 243-48.

13. Danzig BJ. New guidelines for the treatment of acromegaly, a serious growth hormone disorder $2011 ; 1-7$.

14. Tang JA. \& Friedman M. Incidence of Lingual Tonsil Hypertrophy in Adults with and without Obstructive Sleep Apnea. Otolaryngol. Neck Surg 2018; 158: 391-94.

15. Ghatak T, Samanta S, Samanta S. \& Bhagat H. Extubation difficulty after transphenoidal pituitary surgery in an acromegalic patient. Indian J. Anaesth 2013; 57: 322-23.

16. Molitch ME. Diagnosis and treatment of pituitary adenomas: A review. JAMA - J. Am. Med. Assoc 2017; 317: 516-24.
17. Giustina A, Arnaldi G, Bogazzi F, Cannavo S, Colao A, De Marinis L. et al. Pegvisomant in acromegaly: an update. J. Endocrinol. Invest. 2017; 40: 577-89.

18. Katznelson L, Laws ER jr, Melmed S, Molitch ME, Murah MH, Utz A. et al. Acromegaly: an endocrine society clinical practice guideline. J. Clin. Endocrinol. Metab 2014; 99: 3933-51.

19. Sherlock M, Reulen RC, Aragon-Alonso A, Ayuk J, Clayton RN, Sheppard MC. et al. A paradigm shift in the monitoring of patients with acromegaly: last available growth hormone may overestimate risk. J. Clin. Endocrinol. Metab 2014; 99: 478-85.

20. Friedel ME, Johnston DR, Singhal S, Al Khalili K, Farrell CJ, Evans JJ, et al. Airway management and perioperative concerns in acromegaly patients undergoing endoscopic transsphenoidal surgery for pituitary tumors. Otolaryngol. Neck Surg 2013; 149: 840-44. 